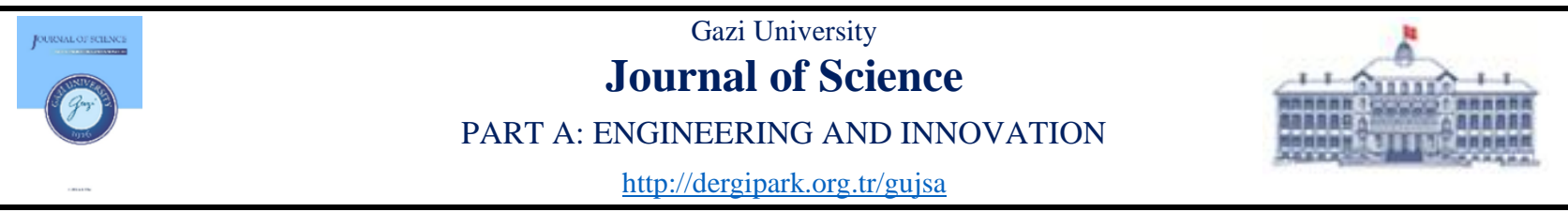

\title{
Synthesis, Spectroscopic and Thermal Characterization of a New Sustainable Polymer
}

\author{
Nevin ÇANKAYA ${ }^{1}$ (iD), \& Nevin TURAN ${ }^{2 *(i D)}$ \\ ${ }^{1}$ Usak University, Department of Chemistry, 64100 Ușak, Turkey \\ ${ }^{2}$ Muş Alparslan University, Department of Chemistry, Faculty of Arts and Sciences, 49250 Muş, Turkey
}

\begin{tabular}{|c|c|}
\hline Keywords & Abstract \\
\hline $\begin{array}{l}\text { D-limonene } \\
\text { Sustainable Polymer } \\
\text { Copolymer } \\
\text { Synthesis and } \\
\text { Characterization } \\
\text { Thermal Stability }\end{array}$ & $\begin{array}{l}\text { Copolymerization is a very important method in the synthesis of products having the physical and } \\
\text { chemical properties sought in industrial sense. In this paper, the copolymerization of N-(4-nitrophenyl) } \\
\text { acrylamide monomer with D-limonene was carried out and LIM-co-NPA copolymer was synthesized } \\
\text { by free radical chain polymerization reaction. The structure of sustainable copolymer of limonene was } \\
\text { chemically characterized by FT-IR, }{ }^{1} \mathrm{H}-\mathrm{NMR} \text { spectroscopic techniques. In addition, thermal stability of } \\
\text { copolymer investigated by TGA/DTG/DTA simultaneous thermal analysis methods. The spectroscopic } \\
\text { results are compatible with the amide or limonene polymers synthesized in the literature. From the } \\
\text { important thermal results of the sustainable copolymer, it has been found that the initial decomposition } \\
\text { temperature is } 226^{\circ} \mathrm{C} \text {, and the maximum decomposition temperatures is } 329^{\circ} \mathrm{C} \text {, glass transition } \\
\text { temperature at } 261^{\circ} \mathrm{C} \text { and crystallization temperature at } 340^{\circ} \mathrm{C} \text {. It can be said that this promising } \\
\text { sustainable copolymer is suitable for other mechanical, physical and biological study and research fields. }\end{array}$ \\
\hline
\end{tabular}

Cite

Çankaya, N., \& Turan, N. (20**). Synthesis, Spectroscopic and Thermal Characterization of a New Sustainable Polymer GU J Sci, Part A, 8(4), 529-536.

\begin{tabular}{lrl}
\hline Author ID (ORCID Number) & Article Process \\
\hline N. Çankaya, 0000-0002-6079-4987 & Submission Date & 22.11 .2021 \\
N. Turan, 0000-0001-6740-6812 & Revision Date & 17.12 .2021 \\
& Accepted Date & 29.12 .2021 \\
& Published Date & 30.12 .2021 \\
\hline
\end{tabular}

\section{INTRODUCTION}

Polymeric materials take part in our daily lives, because they are cheap, easy to produce and chemical resistance. However, owing to the petroleum-based resources of polymer raw materials, the restricted resources of natural monomeric give rise to difficulties about expense and sustainability in the manufacture of these materials. Limonene is a significant workspace for natural polymer resources (Sharma \& Srivastava, 2004; 2006). Limonene is a vigorous, naturally being formed, antinociceptive and antitumor compound present in citrus fruits, such as lemon, grapefruit, oranges, and also in the seeds of caraway and dill (Sun, 2007; Sharma \& Srivastava, 2003). The main component of the bark essence is limonene, constituting about $95 \%$ of it. Dlimonene (1-methyl-4-(1-methylethenyl)cyclohexane), a cyclic monoterpene in lemon flavor, is the main component of citrus peel essential oils (Farhat et al., 2011). The researches have been reported being one of the most plentiful terpenes in cannabis, has $16 \%$ of the essential oil fraction (Sharma \& Srivastava, 2003; Hartsel et al., 2016). D-Limonene, which is used in the food, cosmetics, perfumery, gum, beverage and soap industries, is one of the additives that are generally accepted as safe. D-limonene is used in humans to dissolve cholesterol-containing gallstones and as a chemical preservative in many types of cancer. In addition, it is most commonly used in the treatment of gastric reflux or heartburn due to its gastric acid regulating and normal peristalsis-providing effects (Sun, 2007). In addition, limonene is used in the cosmetic area for aromatic property, in dermatology for percutaneous transfer of drugs, and in food as sweetening (Bacanlı et al., 2018). Many previous studies reported that it has anti-inflammatory and antioxidant features and treatment of many types of cancer such as lung, gastric, hepatocellular carcinoma (Guyton \& Kensler, 2002; Lu et al., 2003; Yu 
et al., 2018; Hajizadeh et al., 2019; Souto et al., 2020). However, low solubility of limonene is a major problem in biological fluids and leads to limited treatment options in cancer therapy (Murali et al., 2013; Hajizadeh et al., 2019).

Due to the limited fossil resources and the worrying plastic accumulation, the development of biobased and sustainable polymers and composites has been a highly studied research topic in recent years (Zhang et al., 2018). Many scientists have stepped up their efforts to design and implement more sustainable approaches for polymer synthesis (Monica \& Kleij, 2020). Various bio-based synthetic polymers can be synthesized from naturally derived monomers and exhibit biodegradability (Neumann et al., 2021).

In this study, copolymer of limonene, a natural monomer, and N-(4-nitrophenyl)acrylamide (NPA), an amide derivative, was synthesized and the characterization results were proven to be compatible with the literature. From the spectroscopic and thermal results, it is thought that this newly synthesized sustainable polymer can find applications in different fields of study.

\section{MATERIAL AND METHOD}

\subsection{Materials}

2,2'-Azobis(isobutyronitrile) (AIBN) as an initiator, chloroform, tetrahydrofuran and N, N-dimethylformamide as a solvent, and also D-limonene (Merck), p-amino nitrobenzene (Across), acryloyl chloride (Merck), triethylamine, were purchased from Aldrich.

\subsection{Synthesis of LIM-co-NPA}

In the presence of $p$-amino nitrobenzene (1.0 mole), acryloyl chloride (1.2 mole) and trimethylamine (1.0 mole), N-(4-nitrophenyl)acrylamide (NPA) monomer was synthesized (Figure 1). Acrylic chloride was diluted with tetrahydrofuran solvent and added dropwise to the solution at $0-5^{\circ} \mathrm{C}$ with continuous stirring. When the exothermic reaction was finished, the solution was filtered, excess solvent was removed and precipitated in ice water. Then, monomer was synthesized by crystallization in chloroform with $65 \%$ yield (Çankaya \& Temüz, 2012; Tanış et al., 2019). Two suitable monomers that D-limonene (1 mole) and NPA (1 mole) with the radical initiator AIBN in $N, N$-dimethylformamide were added the into polymerization flask. The system was kept in inert gas at $65^{\circ} \mathrm{C}$ for $24 \mathrm{~h}$. The synthesized polymer was crystallized several times in ethyl alcohol (Figure 2). (Çankaya \& Temüz, 2012; Çankaya et al., 2019; 2021) and the copolymer was characterized by spectroscopic methods FT-IR and ${ }^{1} \mathrm{H}-\mathrm{NMR}$ (Figure 3 and Figure 4).

\subsection{Instrumental Measurements}

Studies on FT-IR were performed using the Perkin-Elmer Two (UATR) spectrometer. The scanned wavenumbers between 400-4000 $\mathrm{cm}^{-1}$. ${ }^{1} \mathrm{H}-\mathrm{NMR}$ spectrum was conducted on BrukerTopSpinUltraShilt 400 MHz in DMSO- $d_{6}$. Thermal analyze of the copolymer was made with a Hitachi 7000 TGA/DTG/DTA (Thermal Gravimetric Analysis/Differential Thermogravimetric Analysis/Differential Thermal Analysis). Measurement was carried out from room temperature to $600^{\circ} \mathrm{C}$, at a heating rate of $10^{\circ} \mathrm{C} \mathrm{min}^{-1}$ and in a nitrogen atmosphere.

\section{RESULTS AND DISCUSSION}

\subsection{Spectroscopic Characterization of LIM-co-NPA Copolymer}

The copolymer was synthesized by the free radical polymerization method, using AIBN as the initiator (Figure 2). The spectroscopic structure of the LIM-co-NPA was approved by FT-IR and ${ }^{1} \mathrm{H}-\mathrm{NMR}$.

The FT-IR spectrum of the copolymer LIM-co-NPA is indicated in Figure 3. FT-IR $\left(\mathrm{cm}^{-1}\right.$, the most characteristic bands): $1673(\mathrm{C}=\mathrm{O}$ amide stretch), 3311 stretch and 1595 bending vibration $(\mathrm{N}-\mathrm{H}), 2980$ and $2950(\mathrm{C}-\mathrm{Ar}-\mathrm{H}), 1504$ asymmetric and 1330 symmetric stretch $\left(\mathrm{NO}_{2}\right)$ (Sharma \& Srivastava, 2003; 2004; 2006; Çankaya \& Temüz, 2012; Singh \& Kamal, 2012; Brum et al., 2013; Ren et al., 2015; Zhang \& Dubé, 2015; Çankaya et al., 2019; 2021; Tanış et al., 2019; Zhang \& Dubé, 2014). The clear observability of 
characteristic bands in the amide monomer and the absence of alkene bands in the monomers show that our newly synthesized polymer has formed and the literature also support this allegation (Coşkun et al., 2002; Kurt et al., 2019a). Actually, the FT-IR spectrum is the first spectroscopic measurement method that shows us whether newly synthesized materials are formed or not, and has been used in the literature for many years (Turan \& Şekerci, 2009; Temüz, 2017; Coşkun et al., 2019; Kurt et al., 2020).<smiles>C=CC(=O)Nc1ccc([N+](=O)[O-])cc1</smiles>

Figure 1. Synthesis of the N-(4-nitrophenyl)acrylamide (NPA) Monomer<smiles>C=CC(=O)Nc1ccc([N+](=O)[O-])cc1</smiles><smiles>C=C(C)[C@H]1CC=C(C)CC1</smiles>

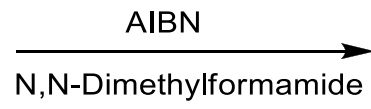

Figure 2. Synthesis of the LIM-co-NPA Copolymer

The ${ }^{1} \mathrm{H}-\mathrm{NMR}$ spectrum of LIM-co-NPA is indicated in Figure 4. In the ${ }^{1} \mathrm{H}-\mathrm{NMR}$ spectrum of the copolymer, the subsequent peaks were seen $\delta(\mathrm{ppm}): \mathrm{N}-\mathrm{H}$ structure at $9.4 \mathrm{ppm}$, ring protons at 8.2 and $7.9 \mathrm{ppm}$, endocyclic and exocyclic $-\mathrm{CH}$ cyclohexene protons at 5.9 and $5.3 \mathrm{ppm}$, limonene $\mathrm{CH}_{3}$ and its cyclohexane $\mathrm{CH}_{2}$ at 2.4 ppm, protons which exist along the polymer chains at 1.4 ppm (Ren et al., 2015; Tanış et al., 2019; Çankaya et al., 2019; 2021). Limonene contains unsaturated endocyclic and exocyclic double bonds. Since endocyclic in double bonds in the limonene ring is more reactive and stable than exocyclic, endo peaks were observed in lower area in NMR results (Brum et al., 2013; Ren et al., 2015; Çankaya et al., 2019; 2021). The data obtained from the ${ }^{1} \mathrm{H}-\mathrm{NMR}$ spectrum were found to be in agreement with the polymers synthesized with limonene in the literature (Sharma \& Srivastava, 2003; 2004; 2006; Singh \& Kamal, 2012; Ren et al., 2015; Zhang \& Dubé 2015; Çankaya et al., 2019; 2021). 


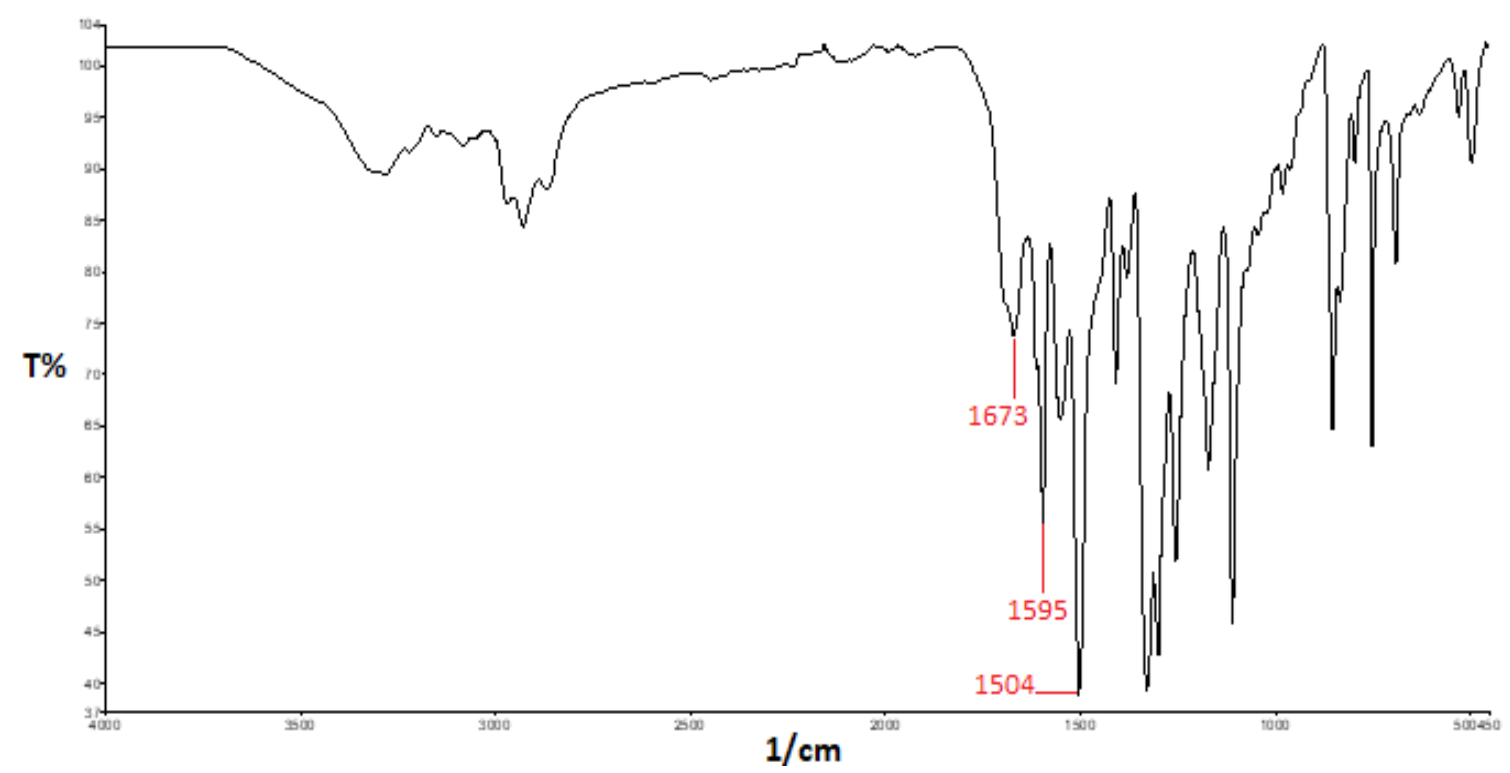

Figure 3. The FT-IR Spectrum of LIM-co-NPA

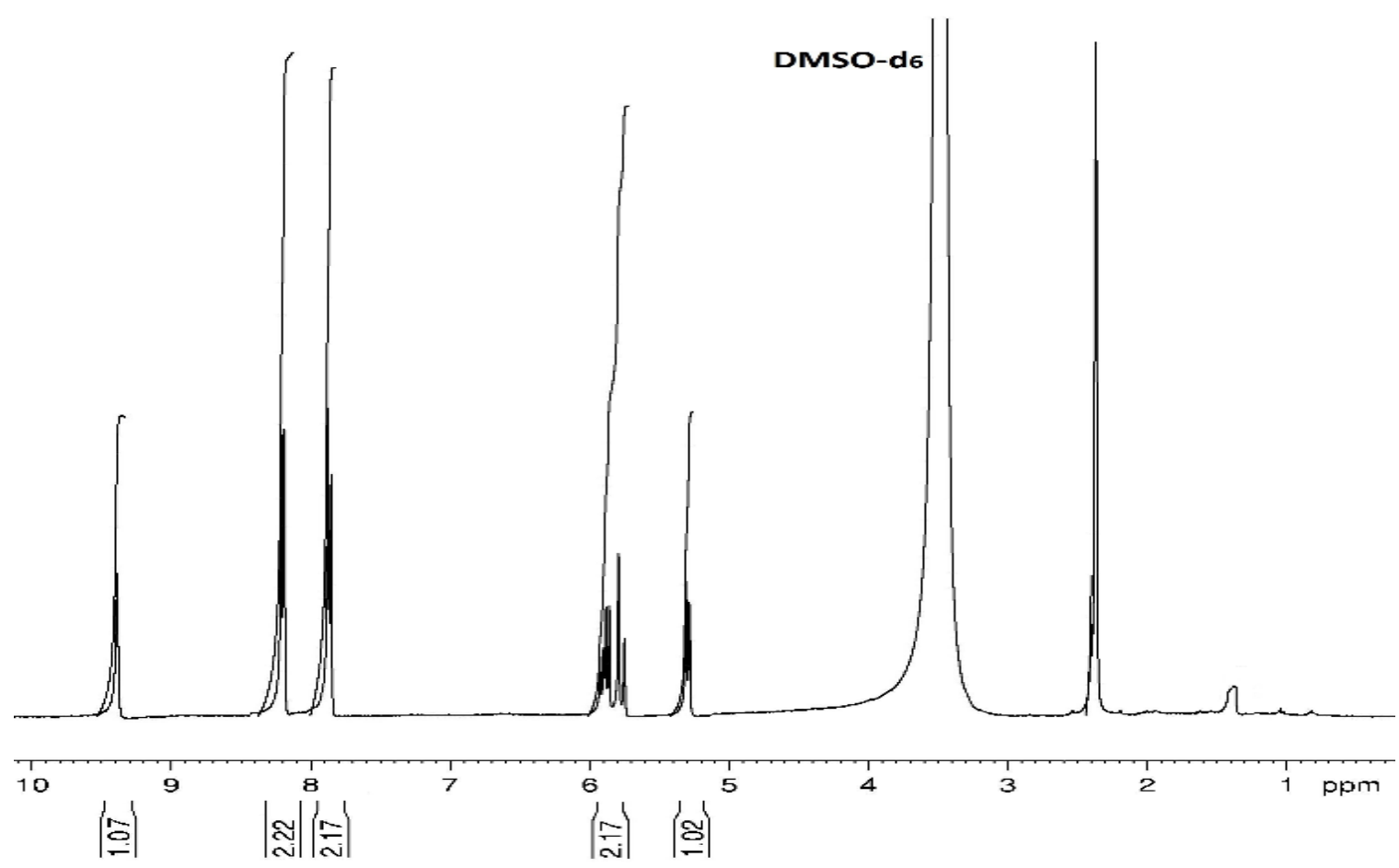

Figure 4. The ${ }^{1} H$-NMR Spectrum of LIM-co-NPA

\subsection{Thermal Characterization of LIM-co-NPA Copolymer}

The thermal features of copolymer were performed by TGA/DTG/DTA simultaneous system, a heating rate of $10^{\circ} \mathrm{C} \mathrm{min}{ }^{-1}$ in nitrogen atmosphere, from room temperature to $600^{\circ} \mathrm{C}$ temperatures. The decomposition temperature and the temperature at weight loss are taken as a measure of thermal stability. Some thermal data such as degradation temperatures at various temperature intervals and mass loss percentages are presented in Table 1. Important thermal results for copolymer; first decomposition temperature was $226^{\circ} \mathrm{C}$, decomposition temperatures were $269^{\circ} \mathrm{C}, 281^{\circ} \mathrm{C}$, and $367^{\circ} \mathrm{C}$ for $20 \%, 25 \%$ and $50 \%$, respectively; weight loss at $400^{\circ} \mathrm{C}$, $450^{\circ} \mathrm{C}$, and $500^{\circ} \mathrm{C}$ were $53 \%, 56 \%$, and $60 \%$ respectively; residue at $500^{\circ} \mathrm{C}, 550^{\circ} \mathrm{C}$ and $600^{\circ} \mathrm{C}$ were $40 \%, 37 \%$ and $35 \%$, respectively. The first and second maximum decomposition temperatures were $261^{\circ} \mathrm{C}$ and $329^{\circ} \mathrm{C}$, respectively. In addition, from the DTA curve, it was seen that $\mathrm{Tg}$ (Glass transition temperature) was $261{ }^{\circ} \mathrm{C}$ and Tc (Crystallization temperature) was $340^{\circ} \mathrm{C}$. The thermal curves of copolymer are given in Figure 5 
(Coşkun et al., 2002; Turan \& Şekerci, 2009; Adiguzel et al., 2011; Arrieta et al., 2013; Brum et al., 2013; Temüz, 2017; Çankaya et al., 2019; 2021; Kurt et al., 2019b; 2020; Bingöl \& Turan, 2020).

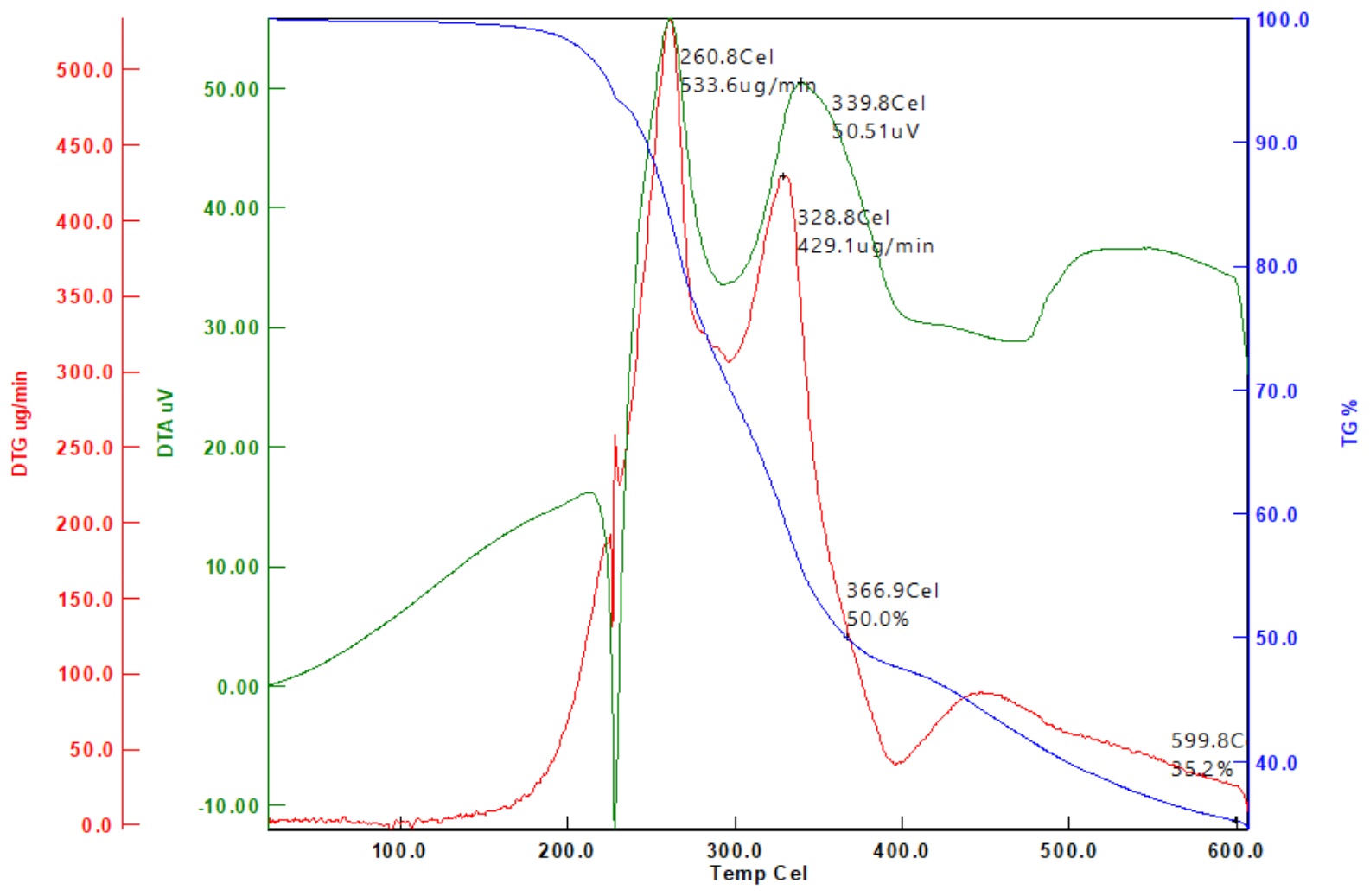

Figure 5. The TGA/DTG/DTA Curves of the LIM-co-NPA Copolymer

Table 1. Some Thermal Data of the LIM-co-NPA Copolymer

\begin{tabular}{ccccc}
\hline Sample & $\begin{array}{c}\text { Maximum } \\
\text { decomposition } \\
\text { temperature }\end{array}$ & $\begin{array}{c}\text { Decomposition } \\
\text { temperature at 20, } \\
\mathbf{2 5} \text { and 50\% }\end{array}$ & $\begin{array}{c}\text { \% Weight loss 400, } \\
\mathbf{4 5 0 , \text { and 500 }}{ }^{\circ} \mathrm{C}\end{array}$ & $\begin{array}{c}\text { \% Residue } \\
\mathbf{5 0 0 , 5 5 0 , 6 0 0}\end{array}$ \\
\hline Copolymer & $261^{\circ} \mathrm{C}$ and $329^{\circ} \mathrm{C}$ & $\begin{array}{c}269^{\circ} \mathrm{C}, 281^{\circ} \mathrm{C} \text {, and } \\
367^{\circ} \mathrm{C}\end{array}$ & $53 \%, 56 \%$, and $60 \%$ & $40 \%, 37 \%$, and $35 \%$ \\
\hline
\end{tabular}

\section{CONCLUSION}

In this study, sustainable poly(D-limonene-co-N-(4-nitrophenyl)acrylamide) (LIM-co-NPA) has been synthesized via free-radical polymerization. The copolymer was characterized by FT-IR and ${ }^{1} \mathrm{H}-\mathrm{NMR}$ spectroscopy techniques. Thermal behavior of copolymer was investigated by the TGA/DTG/DTA simultaneous system. The results obtained from spectroscopic techniques were in agreement with the literature. The thermal stability of the sustainable copolymer was also good. It is hoped that this newly synthesized copolymer will find application in different fields of study in the future.

\section{ACKNOWLEDGEMENT}

The authors thank the Uşak University Research Fund (2014/ÖAP002) for their support for the thermal analyzes of this study.

\section{CONFLICT OF INTEREST}

The authors declare no conflict of interest. 


\section{REFERENCES}

Adiguzel, R., Ergin, Z., Sekerci, M., \& Tascioglu, S. (2011). Synthesis and structural characterization of bis(2amino-1,3,4-thiadiazolyl)methane complexes. Journal of the Chemical Society of Pakistan, 33(2), 238-244.

Arrieta, M. P., López, J., Ferrándiz, S., \& Peltzer, M. A. (2013). Characterization of PLA-limonene blends for food packaging applications. Polymer Testing, 32(4), 760-768. doi:10.1016/j.polymertesting.2013.03.016

Bacanl1, M., Başaran, A. A., \& Başaran, N. (2018). Effects and Usage of a Citrus Compound, Limonene. In: R. R. Watson, V. R. Preedy, \& S. Zibadi (Eds.) Polyphenols: Prevention and Treatment of Human Disease (Second Ed.) (pp. 419-424). Cambridge: Academic Press. doi:10.1016/B978-0-12-813008-7.00032-1

Bingöl, M., \& Turan, N. (2020). Schiff base and metal(II) complexes containing thiophene-3-carboxylate: Synthesis, characterization and antioxidant activities. Journal of Molecular Structure, 1205, 127542. doi:10.1016/j.molstruc.2019.127542

Brum, F. J. B., Laux, F. N., \& Forte, M. M. C. (2013). Synthesis of hydrocarbon polymers by cationic polymerization and their thermal properties. Designed Monomers and Polymers, 16(3), 291-301. doi: $10.1080 / 15685551.2012 .747145$

Coşkun, D., Gündüz, B., \& Coşkun, M. F. (2019). Synthesis, characterization and significant optoelectronic parameters of 1-(7-methoxy-1-benzofuran-2-yl) substituted chalcone derivatives. Journal of Molecular Structure, 1178, 261-267. doi:10.1016/j.molstruc.2018.10.043

Coşkun, M., Erol, İ., Coşkun, M. F., \& Demirelli, K. (2002). Thermal degradation behavior of two methacrylate polymers with side chain amide groups. Polymer Degradation and Stability, 78(1), 49-55. doi:10.1016/S0141-3910(02)00118-0

Çankaya, N., \& Temüz, M. M. (2012). Characterization and monomer reactivity ratios of grafted cellulose with N-(4-nitrophenyl)acrylamide and methyl methacrylate by atom transfer radical polymerization. Cellulose Chemistry and Technology, 46(9-10), 551-558.

Çankaya, N., Tanış, E., Elmalı, H. G., \& Bulut, N. (2019). A new synthesize of limonene copolymer: Experimental and theoretical analysis. Polymer Bulletin, 76(7), 3297-3327. doi:10.1007/s00289-018-2543-3

Çankaya, N., Tanış, E., \& Sapan, P. G. (2021). New synthesis of homopolymer and limonene copolymer: Experimental analysis and density functional theory study. Russian Journal of Physical Chemistry A, 95(1), 139-153. doi:10.1134/S0036024421010052

Farhat, A., Fabiano-Tixier, A-S., Maataoui, M. E., Maingonnat, J-F., Romdhane, M., \& Chemat, F. (2011). Microwave steam diffusion for extraction of essential oil from orange peel: Kinetic data, extract's global yield and mechanism. Food Chemistry, 125(1), 255-261. doi:10.1016/j.foodchem.2010.07.110

Guyton, K. Z., \& Kensler, T. W. (2002). Prevention of liver cancer. Current Oncology Reports, 4(1), 464-470. doi: $10.1007 / \mathrm{s} 11912-002-0057-4$

Hajizadeh, M. R., Maleki, H., Barani, M., Fahmidehkar, M. A., Mahmoodi, M., \& Torkzadeh-Mahani, M. (2019). In vitro cytotoxicity assay of D-limonene niosomes: an efficient nano-carrier for enhancing solubility of plant-extracted agents. Research in Pharmaceutical Sciences, 14(5), 448-458. doi:10.4103/1735$\underline{5362.268206}$

Hartsel, J. A., Eades, J., Hickory, B., \& Makriyannis, A. (2016). Cannabis Sativa and Hemp. In: R. C. Gupta (Eds.) Nutraceuticals: Efficacy, Safety and Toxicity (pp. 735-754). Elsevier Inc: London. doi:10.1016/B978$\underline{0-12-802147-7.00053-X}$

Kurt, A., Gündüz, B., İlter, Z., \& Koca M. (2019a). Optoelectronic properties of 3-acetyl-6-bromocoumarin compound in various solvents and concentrations. Kuwait Journal of Science, 46(3), 60-70.

Kurt, A., Gündüz, B., \& Koca, M. (2019b). A detailed study on the optical properties of 3-benzoyl-7-hydroxy coumarin compound in different solvents and concentrations. Macedonian Journal of Chemistry and Chemical Engineering, 38(2), 227-236. doi:10.20450/mjcce.2019.1403 
Kurt, A., Andan, H., \& Koca, M. (2020). Synthesis and characterization of a new bithiazole-containing conjugated polymer and its thermal decomposition kinetics. Macedonian Journal of Chemistry and Chemical Engineering, 39(2), 227-237. doi:10.20450/mjcce.2020.2025

Lu, X-g., Feng, B-a., Zhan, L-b., \& Yu, Z-h. (2003). D-limonene induces apoptosis of gastric cancer cells. Chinese Journal of Oncology, 25(4), 325-327.

Monica, F. D., \& Kleij A. W. (2020). From terpenes to sustainable and functional polymers. Francesco Polymer Chemistry, 11(32), 5109-5127. doi:10.1039/D0PY00817F

Murali, R., Karthikeyan, A., \& Saravanan, R. (2013). Protective effects of D-limonene on lipid peroxidation and antioxidant enzymes in streptozotocin-induced diabetic rats. Basic \& Clinical Pharmacology \&Toxicology, 112(3), 175-181. doi:10.1111/bcpt.12010

Neumann, S., Hu, P., Bretschneider, F., Schmalz, H., \& Greiner A. (2021). Blends of bio-based poly(limonene carbonate) with commodity polymers. Macromolecular Materials and Engineering, 306(7), 2100090. doi: $10.1002 /$ mame.202100090

Ren, S., Trevino, E., \& Dube, M. A. (2015). Copolymerization of limonene with n-butyl acrylate. Macromolecular Reaction Engineering, 9(4), 339-349. doi:10.1002/mren.201400068

Sharma, S., \& Srivastava, A. K. (2003). Alternating copolymers of limonene with methyl methacrylate: kinetics and mechanism. Journal of Macromolecular Science Part A Pure and Applied Chemistry, 40(6), 593603. doi:10.1081/MA-120020867

Sharma. S., \& Srivastava, A. K. (2004). Synthesis and characterization of copolymers of limonene with styrene initiated by azobisisobutyronitrile. European Polymer Journal, 40(9), 2235-2240. doi:10.1016/j.eurpolymj.2004.02.028

Sharma, S., \& Srivastava, A. K. (2006). Radical co-polymerization of limonene with N-vinyl pyrrolidone: Synthesis and characterization. Designed Monomers and Polymers, 9(5), 503-516. doi: $\underline{10.1163 / 156855506778538001}$

Singh, A., \& Kamal, M. (2012). Synthesis and characterization of polylimonene: Polymer of an optically active terpene. Journal of Applied Polymer Science, 125(2), 1456-1459. doi:10.1002/app.36250

Souto, E. B., Zielinska, A., Souto, S. B., Durazzo, A., Lucarini, M., Santini, A., Silva, A. M., Atanasov, A. G., Marques, C., Andrade, L. N., \& Severino, P. (2020). (+)-Limonene 1,2-epoxide-loaded SLNs: Evaluation of drug release, antioxidant activity, and cytotoxicity in an HaCaT cell line. International Journal of Molecular Sciences, 21(4), 1449. doi:10.3390/ijms21041449

Sun, J. (2007). D-limonene: Safety and clinical applications. Alternative Medicine Review-A Journal of Clinical Therapeutics, 12(3), 259-264. PubMed:18072821

Tanış, E., Çankaya, N., \& Yalçın, S. (2019). Synthesis, characterization, computation of global reactivity descriptors and antiproliferative activity of N-(4-nitrophenyl)acrylamide. Russian Journal of Physical Chemistry B, 13(1), 49-61. doi:10.1134/S1990793119010147

Temüz, M. M. (2017). Radical copolymerization of acrloylmorpholine with 2-hydroxyethyl methacrylate: Monomer reactivity ratios and thermal properties. Anadolu University Journal of Science and Technology AApplied Sciences and Engineering, 18(5), 929-938. doi:10.18038/aubtda.306626

Turan, N., \& Şekerci, M. (2009). Metal complexes of Schiff base derived from terephthalaldehyde and 2amino-5-ethyl-1,3,4-thiadiazole synthesis, spectral and thermal characterization. Synthesis and Reactivity in Inorganic Metal-Organic and Nano-Metal Chemistry, 39(10), 651-657. doi:10.1080/15533170903433162

Yu, X., Lin, H., Wang, Y., Lv, W., Zhang, S., Qian, Y., Deng, X., Feng, N., Yu, H., \& Qian, B. (2018). Dlimonene exhibits antitumor activity by inducing autophagy and apoptosis in lung cancer. OncoTargets and Therapy, 11, 1833-1847. doi:10.2147/OTT.S155716

Zhang, X., Fevre, M., Jones, G. O., \& Waymouth, R. M. (2018). Catalysis as an enabling science for sustainable polymers. Chemical Reviews, 118(2), 839-885. doi:10.1021/acs.chemrev.7b00329 
Zhang, Y., \& Dubé, M. A. (2014). Copolymerization of $N$-butyl methacrylate and D-limonene. Macromolecular Reaction Engineering, 8(12), 805-812. doi:10.1002/mren.201400023

Zhang, Y., \& Dubé, M. A. (2015). Copolymerization of 2-ethylhexyl acrylate and D-limonene, copolymerization of 2-ethylhexyl acrylate and D-limonene. Polymer-Plastics Technology and Engineering, 54(5), 499-505. doi:10.1080/03602559.2014.961080 